\title{
HEALTH CARE ACCESSIBILITY FOR INDIVIDUALS WITH DISABILITIES: BARRIERS AND RISK FACTORS IMPACTING CARE
}

\author{
Abbey Senczyszyn*, J. Chad Duncan \\ Northwestern University Prosthetics-Orthotics Center, USA. \\ *Email: abbey.senczyszyn@northwestern.edu
}

DOI: https://doi.org/10.33137/cpoj.v1i2.32046

\section{BACKGROUND}

Healthcare professionals have certain professional, legal, and ethical obligations that they must fulfill with each patient interaction. Though professional and legal obligations may vary between fields of practice, the core ethical responsibility remains the same: provide just health care ${ }^{1}$. This requires that healthcare professionals are aware of systemic and institutional factors that lead to disparity and discrimination in the provision of health services ${ }^{1}$. Disability is a complex construct that can be related to various factors related to health condition as well as social and environmental factors that influence participation. This complexity results in varying definitions; the ICF model of disability was used in this research ${ }^{2}$.

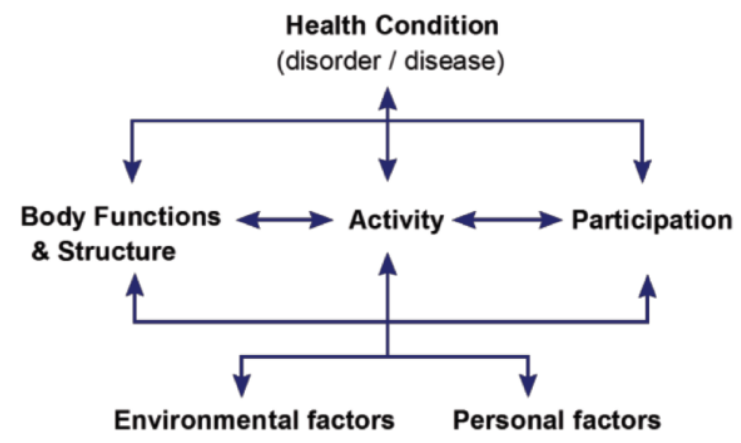

Figure 1. ICF Framework ${ }^{2}$

\section{METHODS}

\section{Inclusion Criteria:}

- Health care in the United States

- Individuals with a physical disability or limitation

- Discussion of disparity and accessibility related to the provision of healthcare

- Publication date of January 1, 2014 or later

- Data from 2010 or later

- Age 18 and older

\section{Exclusion Criteria:}

- Studies irrelevant to health care in the United States

- Individuals with a mental disability or hard of hearing

- Specialty care irrelevant to the purposes of this study

- Pediatric patient population

- Full text not available.

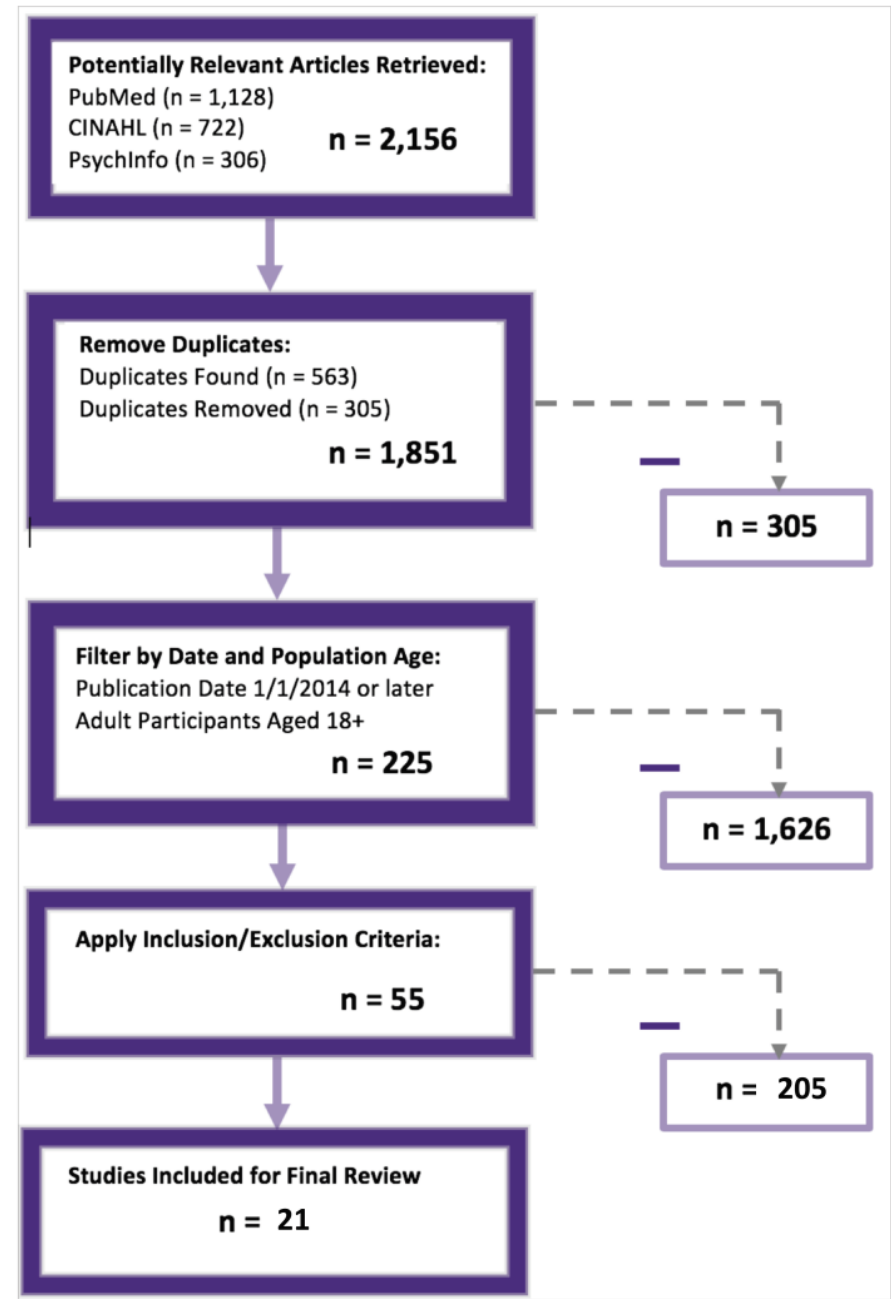




\section{PRELIMINARY RESULTS: ACCESS}

\section{BARRIERS}

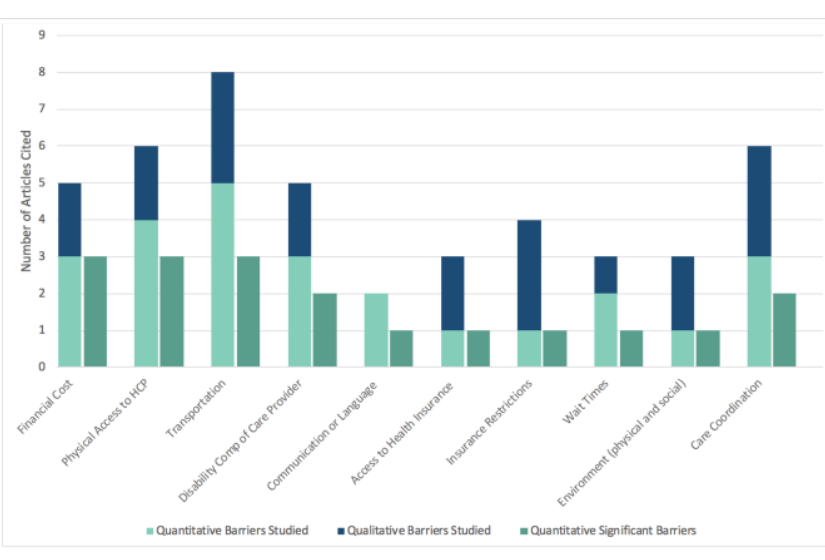

Figure 2. Commonly cited barriers preventing access to healthcare evaluated in current literature ${ }^{3,5-8,10-12,15,20-21}$

\section{PRELIMINARY RESULTS: RISK FACTORS}

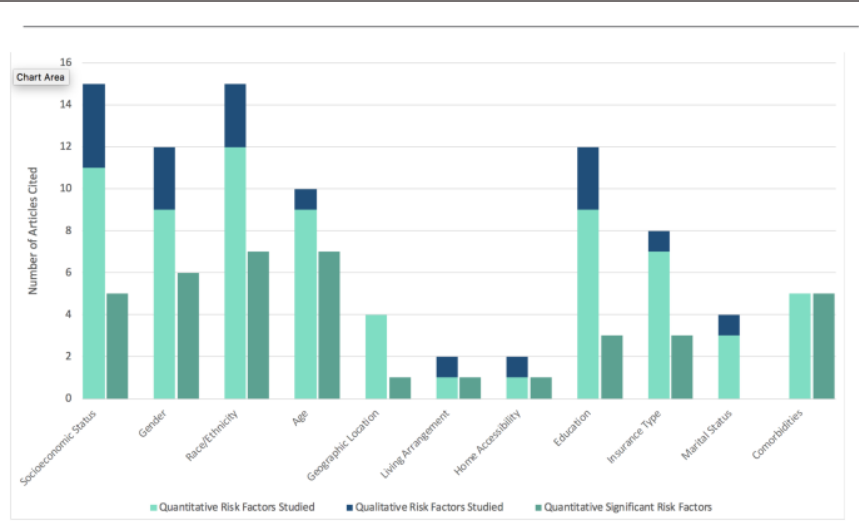

Figure 3. Commonly cited risk factors potentially resulting in healthcare disparity evaluated in current literature ${ }^{3-5,8-11,13-14,16-}$ 22.

\section{LIMITATION}

- Non-homogenous populations

- Varying data sources.

\section{DISCUSSION}

Disparity in the provision of health care is not a new topic of discussion; however, past research has primarily focused on age, racial/ethnic, and socioeconomic disparities related to health care. Recently, arguments have been made that people with disability also experience disparity in the receipt of health care services.
This research sought to compile the most commonly cited factors that are thought to factor into this inequality. Despite the implementation of various legislative measures including the Americans with Disability Act and, more recently, the Patient Protection and Affordable Care Act, disparity still exists in the provision of health care. The most commonly cited barriers include transportation ${ }^{5,7,9-11,14,19-20,}$ care coordination ${ }^{4-5,9-11,14,}$ and physical access to a health care provider ${ }^{7,10-11,14,19-20 .}$ Certain groups are more likely to experience these barriers to care, the most commonly cited significant

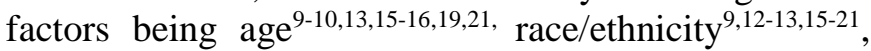
and gender ${ }^{10,15,18-19}$.

\section{REFERENCES}

1. American Society for Bioethics and Humanities. (2011). Core Competencies for Healthcare Ethics Consultation (2nd ed.). Glenview, IL: Author.

2. World Health Organization. International Classification of Functioning, Disability, and Health. Geneva, Switzerland: World Health Organization; 2001.

3. Gulley SP, Rasch EK, Chan L. Difference, disparity, and disability: a comparison of health, insurance coverage, and health service use on the basis of race/ethnicity among US adults with disabilities, 2006-2008. Medical care. 2014;52(10 Suppl 3):S9-16. DOI:10.1097/MLR.0000000000000129

4. Bogner et al. Patient Satisfaction and Perceived Quality of Care Among Older Adults According to Activity Limitation Stages. Archives of physical medicine and rehabilitation. 2015;96(10):1810-9. DOI:10.1016/j.apmr.2015.06.005

5. Hall JP, Kurth NK, Chapman SL, Shireman TI. Medicaid managed care: issues for beneficiaries with disabilities. Disability and health journal. 2015;8(1):130-5. DOI: 10.1016/j.dhjo.2014.08.010

6. Kennedy J, Wood EG, Frieden L. Disparities in Insurance Coverage, Health Services Use, and Access Following Implementation of the Affordable Care Act: A Comparison of Disabled and Nondisabled Working-Age Adults. Inquiry : a journal of medical care organization, provision and financing. 2017. DOI: $10.1177 / 0046958017734031$

7. Krahn GL, Walker DK, Correa-De-Araujo R. Persons with disabilities as an unrecognized health disparity population. American journal of public health. 2015;105 Suppl 2:S198206. DOI: 10.2105/AJPH.2014.302182

8. Lin S-F, Beck AN, Finch BK. Black-white disparity in disability among U.S. older adults: Age, period, and cohort trends. The Journals of Gerontology: Series B: Psychological Sciences and Social Sciences. 2014;69(5):784-97. https://doi.org/10.1093/geronb/gbu010 
9. McClintock HF, Kurichi JE, Kwong PL, Xie D, Streim JE, Pezzin LE, et al. Disability Stages and Trouble Getting Needed Health Care Among Medicare Beneficiaries. American journal of physical medicine \& rehabilitation. 2017;96(6):408-16. DOI: $10.1097 /$ PHM.0000000000000638

10. Pezzin LE, Bogner HR, Kurichi JE, Kwong PL, Streim JE, Xie D, et al. Preventable hospitalizations, barriers to care, and disability. Medicine. 2018;97(19):e0691. DOI: 10.1097/MD.0000000000010691

11. Bauer SE, Schumacher JR, Hall A, Marlow NM, Friedel C, Scheer D, et al. Disability and physical and communicationrelated barriers to health care related services among Florida residents: A brief report. Disability and health journal. 2016;9(3):552-6. DOI:10.1016/j.dhjo.2016.03.001

12.Brenner AB, Clarke PJ. Understanding Socioenvironmental Contributors to Racial and Ethnic Disparities in Disability Among Older Americans. Research on Aging. 2018;40(2):103-30. DOI:10.1177/0164027516681165

13.Brucker DL, Rollins NG. Trips to medical care among persons with disabilities: Evidence from the 2009 National Household Travel Survey. Disability and health journal. 2016;9(3):539-43. DOI:10.1016/j.dhjo.2016.01.001

14. de Vries McClintock HF, Barg FK, Katz SP, Stineman MG, Krueger A, Colletti PM, et al. Health care experiences and perceptions among people with and without disabilities. Disability and health journal. 2016;9(1):74-82. DOI: $\underline{10.1016 / \text { j.dhjo.2015.08.007 }}$

15. Dobbertin K, Horner-Johnson W, Lee JC, Andresen EM. Subgroup differences in having a usual source of health care among working-age adults with and without disabilities. Disability and health journal. 2015;8(2):296-302. DOI: 10.1016/j.dhjo.2014.08.012

16. Gimm G, Blodgett E, Zanwar P. Examining access to care for younger vs. older dual-eligible adults living in the community. Disability and health journal. 2016;9(3):431-8. DOI:10.1016/j.dhjo.2015.12.004

17. Horner-Johnson W, Dobbertin K. Usual source of care and unmet health care needs: interaction of disability with race and ethnicity. Medical care. 2014;52(10 Suppl 3):S40-50. DOI: $10.1097 / M L R .0000000000000193$

18. Mahmoudi E, Meade MA. Disparities in access to health care among adults with physical disabilities: Analysis of a representative national sample for a ten-year period. Disability and health journal. 2015;8(2):182-90. DOI: $\underline{10.1016 / \text { j.dhjo.2014.08.007 }}$
19. Ryan J, Abrams MK, Doty MM, Shah T, Schneider EC. How High-Need Patients Experience Health Care in the United States. Findings from the 2016 Commonwealth Fund Survey of High-Need Patients. Issue brief (Commonwealth Fund). 2016;43:1-20.

20. Stillman MD, Frost KL, Smalley C, Bertocci G, Williams $\mathrm{S}$. Health care utilization and barriers experienced by individuals with spinal cord injury. Archives of physical medicine and rehabilitation. 2014;95(6):1114-26. DOI: $\underline{10.1016 / j . a p m r .2014 .02 .005}$

21. Torres H, Poorman E, Tadepalli U, et al. Coverage and access for Americans with chronic disease under the Affordable Care Act. Ann Intern Med. 2017; 166(7):472-479. DOI: $10.7326 / \mathrm{M} 16-1256$

\section{ACKNOWLEDGEMENTS \& DISCLOSURE}

I would like to thank Dr. J. Chad Duncan for his help during this project: providing guidance and feedback during the development of this research. This research was developed as part of the NUPOC curriculum. No funding sources or sponsorships were provided during the completion of this research. 